\title{
Effect of dietary fiber in lowering serum glucose and body weight in sprague dawley rats
}

\section{Masood Sadiq Butt, Naureen Shahzadi, Hafiz Ansar Rasul Suleria, Tauseef Sultan and Muhammad Imran Chohan}

National Institute of Food Science and Technology, University of Agriculture Faisalabad, Pakistan

Corresponding Author: Hafiz Ansar Rasul Suleria, National Institute of Food Science and Technology, University of Agriculture, Faisalabad, Pakistan

Submission date: May 26, 2011; Acceptance date: August 28, 2011; Publication date: August 31, 2011

\begin{abstract}
Introduction:

The present study evaluated the hypoglycemic perspectives and weight loss significance of dietary fiber. Dietary fiber was supplemented in commercial wheat flour (atta) for the preparation of chapaties, a staple diet of South Asia. Male Sprague Dawley rats $(\mathrm{n}=100)$ were randomly divided into 4 diet groups ( $n=25$ per group). The control group was fed basal diet that included commercial wheat flour chapati, cornstarch, corn oil, salt and vitamin mixture in such a way that $10 \%$ of the protein was available from the final diet. To the basal diet of other 3 groups, chapaties supplemented with 2\% guar gum (GG 2\%), 3\% guar gum (GG 3\%) and 5\% chickpea + $1 \%$ guar gum (CP5\%+GG1\%) were added, respectively. All diets were fed to the rats for a period of 8 weeks to perceive the impact of respective compositions. Rats fed on CP 5\% + GG $1 \%$, showed maximum glucose reduction (14.57\%) followed by GG 3\% (11.64\%) and GG 2\% (9.60\%) as compared to control diet. Likewise, rats fed on 3\% GG showed maximum decline (7.90\%) in body weight. It was concluded that chapaties prepared from selected treatments provide an additional dietary fiber that could be supportive for diabetic and obese individuals.
\end{abstract}

\section{Results:}

The results indicated that addition of dietary fiber influenced the physical characteristics of chapati non-significantly. Maximum glucose concentration was found to be $112.50 \mathrm{mg} / \mathrm{dL}$ in control group followed by 101.70 and $99.41 \mathrm{mg} / \mathrm{dL}$ in groups fed on guar gum $2 \%$ and guar gum $3 \%$, respectively. Lowest glucose concentration $(96.11 \mathrm{mg} / \mathrm{dL})$ was observed in rats fed on the combination of chickpea $5 \%+$ guar gum $1 \%$. Maximum serum protein concentration was found to be $6.39 \mathrm{~g} / \mathrm{dL}$ in rats fed on combination of chickpea $5 \%$ + guar gum $1 \%$ whilst the remaining three groups showed non significant variations with respect to each other. Means for serum 
protein were $6.33,6.30$ and $6.32 \mathrm{~g} / \mathrm{dL}$ for control, guar gum $3 \%$, and guar gum $2 \%$, respectively. Maximum serum albumin concentration was found to be $3.63 \mathrm{~g} / \mathrm{dL}$ in rats fed on combination of chickpea 5\%+ guar gum $1 \%$ showing non-significant differences than that of control $(3.60 \mathrm{~g} / \mathrm{dL})$.

\section{Conclusion}

Soaring cost of medication and their side effects demand new ways against the existing malady of diabetes. Diet based strategy is a right approach as it is economical and assessable to avoid the health risks. The present research explored that diet diversification is an effective tool for the management of serum glucose and body weight. Role of legumes is indispensable to enhance the dietary fiber. Ingestion of chapaties prepared from selected compositions of composite flours providing an additional dietary fiber would be supportive to reduce hyperglycemia and obesity.

Keywords: Sprague Dawley rats, Dietary fiber, Composite flour, Chapati, Serum glucose, Insulin glucose indices.

\section{BACKGROUND:}

Studies on the composite flours containing wheat and legumes have been carried out in various parts of the world to explore their therapeutic and medicinal role. Legumes are not only important to improve the nutritional status of the diet but also for the preparation of fiber enriched products. It is apparent that composite flour prepared by blending wheat and legumes in proper proportions may increase the fiber content of the diet resulting in easiest bowel movement, reduction in cholesterol level in serum and liver and beneficial effects particularly to the diabetics $[1,2]$. Legumes are the second to cereals as essential sources of dietary fibers. Chickpea, pigeon pea, mung bean, urad bean, lentil and field pea are the pulse crops of significant dietary and economic importance in the sub-continent [3].

Total dietary fiber includes all food components that are not broken down by human alimentary tract enzymes to assailable fragments [4]. Dietary fiber adds no calories to the diet. It may protect against diabetes and obesity [5]. Wheat contains $12 \%$ of total fiber out of which 9$11 \%$ is insoluble while the remaining 1-3\% comprised of soluble fiber [6]. In case of legumes, total dietary fiber content ranged from 10.7-14.3\% [7]. According to another study, chickpea and lentil have dietary fiber content $16.3 \%$ and $15.9 \%$, respectively [8]. Guar gum (GG) contains $75 \%$ soluble fiber and $7.6 \%$ insoluble fibers [9]. Water-soluble dietary fiber acts like a sponge and absorbs water in the intestine, mixes the food into gel and there by slows down the rate of digestion and absorption. Glycemic index of pulses and legumes have generally ranged from 20 to $50 \%$ of that of white bread [10]. Owing to the enormous functions of GG, United States (US) imports more than 96 million pounds of GG from India and Pakistan annually [11].

Cereal grains and legumes play an important role in supplying the nutrients, as well as over $70 \%$ of the daily energy requirements [12]. In Pakistan, $80 \%$ of the wheat flour produced is utilizing in the form of unleavened flat bread locally known as Chapati, a staple diet of South Asia while the rest $20 \%$ is using in bakery section. More than $60 \%$ of the total daily requirement of protein and calories of Pakistani people are met through wheat [13]. When a staple food that is 
consumed regularly by the masses is used as a vehicle, high population coverage can easily be achieved [14]. Therefore, chapaties prepared by blending wheat flour with lentil, chickpea, and GG can be beneficial for the normal individuals as well as hyperglycemic patients. During in vitro degradation studies, highly significant decline in sugar release by dietary fiber enriched biscuits is shown. This has a beneficial effect in potentially reducing the glycemic index and subsequent glycemic loading of such foods [15]. In Pakistan, chickpea flour was blended with wheat flour to bake "basini roti" that is unleavened bread commonly consumed by diabetic patients [16]. Wheat flour can be enriched with pulses up to $10 \%$ to produce bread of acceptable quality [17]. Consumption of composite flour bread prepared with 5\% guar gum and 5\% wheat bran decreased the level of postprandial blood glucose when compared to the level of fasting blood glucose. The effect of guar gum on reduction in postprandial glycemia was due to delayed passage of guar gum containing meal through the stomach and small intestine, also might be due to the viscous nature of the meal resisting the propulsive and mixing effects of the gastrointestinal contractions, thereby reducing access of the glucose to the absorptive epithelium $[18,19]$. Guar gum can be effectively used to reduce postprandial blood glucose [20]. The acute effect of a single dose of guar gum has been verified to reduce the peak postprandial whole blood glucose levels (about 10\%). Following long-term treatment, a further reduction was seen in the obese subjects with the highest postprandial glucose levels [21].

Dietary fiber certainly has some potential in the management of weight loss. This effect is derived from the potential influence of fiber on several aspects of food intake and nutrient availability [22]. The effects on weight loss are often deduced from effects on satiety, decreased caloric intake, and increased fecal excretion of energy in the form of fat and nitrogen [23-25]. It has been found that gel-forming fibers such as guar gum and pectin are more effective in promoting weight reduction than non-gel forming fibers like wheat bran [26]. Supplementing a normal diet with gel-forming fibers, such as guar gum leads to an increased satiation probably due to slow gastric emptying. A long term studied had confirmed the usefulness of viscous fibers as an adjunct to regular dietary treatment of obesity [27]. The long-term effects of guar gum in male adolescent rats were studied; the guar gum group consumed less diet throughout the entire study and gained less weight over the first 20 weeks as compared to the cellulose and bran groups [28]. Rats fed on guar gum had reduced feed intake and body weight gain [9]. Guar gum (10 and $20 \mathrm{~g} / \mathrm{Kg}$ in diet) can slow the mechanical disruption of food in the stomach and thereby impede the delivery of nutrients to the small intestine [29]. Modified guar gum has appeared to affect appetite and body weight (BW) loss in humans. A significant decrease in body weight (62.9 \pm 2.9 vs. $60.4 \pm 2.2 \mathrm{~kg}$ in paired comparison) in subjects receiving guar gum was observed in middle-aged females [30]. In contrast, a gain in body weight of rats fed on fortified samples of wheat with gram flour was reported [31]. Comparative diets containing zero, 50 and $100 \mathrm{~g} / \mathrm{Kg}$ GG were fed to male Wistar rats for 21 days. Weight gain over the balanced period and feed conversion ratio decreased linearly with increasing GG intake [32].

Raw legume feeding resulted in greater pancreatic and small intestine weight relative to body weight [33]. Diets containing 0,10 and $20 \%$ guar gum were fed to normal male wistar rats $(107.0 \pm 9.3 \mathrm{~g})$ for 60 days, which showed $10 \%$ increase in small intestine length [9]. In another study, significant increase in small intestinal length was found in guar-supplemented rats [34]. In 
Pakistan, to control obesity and diabetes, little efforts are being carried out through diet diversification programs. It is the dire need to increase dietary fiber in the diet of vulnerable group by blending high dietary fiber commodities in the staple diet i.e. chapati to reduce the threat of glycemic indices and obesity. For this purpose, research trials were conducted on male Sprague Dawley rats to find out the impact of composite flour chapaties with special reference to serum glucose and gain in body weight to attain the conclusive approach.

\section{MATERIALS AND METHODS}

The research was carried out in National Institute of Food Science \& Technology, University of Agriculture, Faisalabad-Pakistan.

\section{Raw Material}

Commercial wheat flour (atta), guar gum (Cyamopsis tetragonolobus), lentil (Lens culinaris), and chickpea (Cicer arietinum) were purchased from the market to make composite flour compositions for chapati preparation.

\section{Preparation of Composite Flours}

Wheat flour was blended with lentil, chickpea and guar gum flours in different combinations as mentioned in Table 1. Each composition of composite flour was thoroughly mixed to achieve a uniform dispersion of legume flour particles with wheat flour. Three homogenous replicates for each composite flour was taken and stored at room temperature in woven polypropylene bags.

Table 1. Different combinations used to prepare composite flours.

\begin{tabular}{ccccc}
\hline Treatments & Wheat flour $\%$ & Lentil \% & Chickpea $\%$ & Guar gum \% \\
\hline $\mathrm{T}_{1}$ & 100 & - & - & - \\
$\mathrm{T}_{2}$ & 95 & 5 & - & - \\
$\mathrm{T}_{3}$ & 92.5 & 7.5 & - & - \\
$\mathrm{T}_{4}$ & 90 & 10 & 5 & - \\
$\mathrm{T}_{5}$ & 95 & - & 7.5 & - \\
$\mathrm{T}_{6}$ & 92.5 & - & 10 & - \\
$\mathrm{T}_{7}$ & 90 & - & - & 1 \\
$\mathrm{~T}_{8}$ & 99 & - & - & 2 \\
$\mathrm{~T}_{9}$ & 98 & - & - & 3 \\
$\mathrm{~T}_{10}$ & 97 & - & - & 1 \\
$\mathrm{~T}_{11}$ & 94 & 5 & - & 1 \\
$\mathrm{~T}_{12}$ & 91.5 & 7.5 & - & 1 \\
$\mathrm{~T}_{13}$ & 89 & 10 & 5 & 1 \\
$\mathrm{~T}_{14}$ & 94 & - & & \\
\hline
\end{tabular}




\begin{tabular}{ccccc}
\hline $\mathrm{T}_{15}$ & 91.5 & - & 7.5 & 1 \\
$\mathrm{~T}_{16}$ & 89 & - & 10 & 1 \\
\hline
\end{tabular}

- $\mathrm{T}_{1}$ (commercial wheat flour) acts as control

\section{Preparation of Chapaties}

Chapaties of uniform thickness $(3 \mathrm{~mm})$ and weight $(100 \mathrm{~g})$ was prepared and baked at different intervals on a thermostatically controlled hot plate at a temperature of $210{ }^{\circ} \mathrm{C}$ for 2.5 minutes [35].

\section{Dietary Fiber}

Composite flours and resultant chapaties were evaluated on dry weight basis for dietary fiber at 0,30 , and 60 days interval by a combination of enzymatic and gravimetric procedures [36].

\section{Sensory Evaluation}

The Sensory evaluation of chapaties was carried out for various attributes to determine the total chapati scores at stated intervals by a trained taste panel using 9-point hedonic scale system [37].

\section{Selection of Best Compositions}

Based on the better performance of samples for product preparation regarding sensory attributes of chapaties and dietary fiber three best compositions along with control were selected. These samples were used further for efficacy purposes.

\section{Efficacy Studies}

Animal Care Committee of National Institute of Food Science and Technology, University of Agriculture, Faisalabad approved the study. Efficacy studies were conducted on four groups of male Sprague Dawley rats $(\mathrm{n}=100)$, twenty-five in each group (each rat in an individual cage) to determine the effect of three best-selected compositions with that of control on serum profile with special reference to glucose, protein, and albumin. The rats were fed on freshly prepared diets (Table 2) and water on daily basis up to 8 weeks.

Table 2 Composition of experimental diets.

\begin{tabular}{lllll}
\hline Ingredients & \multicolumn{1}{c}{$\mathrm{A}$} & \multicolumn{1}{c}{$\mathrm{B}$} & $\mathrm{C}$ & $\mathrm{D}$ \\
\hline Chapati $(\mathrm{g})$ & 85.84 & 87.72 & 87.11 & 83.40 \\
Corn Starch $(\mathrm{g})$ & 4.66 & 2.78 & 3.39 & 7.10 \\
Corn oil $(\mathrm{ml})$ & 5.00 & 5.00 & 5.00 & 5.00 \\
*Salt mixture $(\mathrm{g})$ & 3.50 & 3.50 & 3.50 & 3.50 \\
**Vitamin mixture $(\mathrm{g})$ & 1.0 & 1.0 & 1.0 & 1.0 \\
Total $(\mathrm{g})$ & 100 & 100 & 100 & 100 \\
Protein from all sources & 10.01 & 10.02 & 10.00 & 10.00 \\
\hline
\end{tabular}

$\mathrm{A}=(\mathrm{Control}$ diet $)$ prepared from chapati containing $100 \%$ commercial wheat flour

$\mathrm{B}=$ Diet containing guar gum $3 \%$

$\mathrm{C}=$ Diet containing guar gum $2 \%$

$\mathrm{D}=$ Diet containing chickpea $5 \%+$ guar gum $1 \%$ 
*Salt mixture (Calcium citrate, $\mathrm{Ca}\left(\mathrm{H}_{2} \mathrm{PO}_{4}\right)_{2} \mathrm{H}_{2} \mathrm{O}, \mathrm{H}_{2} \mathrm{HPO}_{4}, \mathrm{NaCl}, \mathrm{CaCO}_{3}, 3 \mathrm{MgCO}_{3} . \mathrm{Mg}(\mathrm{OH})_{2} .3 \mathrm{H}_{2} \mathrm{O}, \mathrm{MgSO}_{4}$ anhydrous, Ferric ammonium citrate, $\mathrm{CuSO}_{4} .5 \mathrm{H}_{2} \mathrm{O}, \mathrm{NaF}, \mathrm{MnSO}_{4} .2 \mathrm{H}_{2} \mathrm{O}, \mathrm{KAl}\left(\mathrm{SO}_{4}\right)_{2} .12 \mathrm{H}_{2} \mathrm{O}$ and $\left.\mathrm{KI}\right)$

**Vitamin mixture (Thiamin hydrochloride, riboflavin, pyridoxin hydrochloride, calcium, pentothenate, nicotinic acid, inositol, p-aminobenzoic acid, biotin, folic acid, cyanocobalamin, choline chloride and maize starch)

The feed intake of individual rat was determined by deducting the leftover and spilled over diet from the total amount supplied per day. Gain in body weight of individual rat in each group was determined on weekly basis throughout the experimental period to find out the effect of individual diet on body weight. The temperature $23 \pm 2{ }^{\circ} \mathrm{C}$ and 12 hours lighting period were maintained through out the experimental period. At the end of the trial after eight weeks, the overnight fasted rats were decapitated and the blood samples were collected. Glucose concentration of individual rats in each group was calculated by GOD-PAP method [38]. Similarly, serum protein was determined by Biuret method [39] where as albumin concentration was determined by Bromcresol Green method [40]. After serum collection, the organs i.e. liver, heart, lungs, spleen, right kidney, left kidney, and small intestine were separated and weighed to determine the effect of experimental diets. The intestine length was also measured with the help of scale.

\section{Statistical Analysis}

Analysis of variance was carried out to determine the level of significance by applying completely randomized design by using Minitab® 15 Statistical Software [41].

\section{RESULTS}

Dietary Fiber: The means for dietary fiber content in composite flour samples and resultant chapaties have been shown in Table 3.

Table 3. Dietary fiber content (\%) of composite flours and chapaties (Means \pm standard deviation).

\begin{tabular}{lcccccc}
\hline & Control & GG 3\% & GG 2\% & CP5\%+GG1\% & $\begin{array}{c}\text { P } \\
\text { value }\end{array}$ & $\begin{array}{c}\text { Confidence } \\
\text { Intervals }\end{array}$ \\
\hline $\begin{array}{l}\text { Composite } \\
\text { flours }\end{array}$ & $6.72^{\mathrm{d}} \pm 0.19$ & $8.15^{\mathrm{b}} \pm 0.0 .25$ & $8.85^{\mathrm{a}} \pm 0.22$ & $7.90^{\mathrm{c}} \pm 0.22$ & 0.000 & $7.46-8.34$ \\
$\begin{array}{l}\text { Composite flour } \\
\text { chapaties }\end{array}$ & $6.03^{\mathrm{c}} \pm 0.18$ & $7.48^{\mathrm{b}} \pm 0.22$ & $\begin{array}{c}8.16 \\
{ }^{\mathrm{a}} \pm 0.20\end{array}$ & $7.28^{\mathrm{bc}} \pm 0.23$ & 0.000 & $6.79-7.68$ \\
\hline
\end{tabular}

Means showing similar lettering in a row were not statistically different to each at $1 \%$ level of significance

Control=Commercial wheat flour; GG3\% = Guar gum 3\%; GG2\% = Guar gum 2\%; CP+GG = Chickpea 5\% + Guar gum 1\%;

It is obvious from the results that variation $(\mathrm{P}<0.000)$ exists within various compositions of composite flours. Maximum dietary fiber $8.85 \%$ was observed in $\mathrm{T}_{10}$ (guar gum $3 \%$ ) followed by $8.15 \%$ in $\mathrm{T}_{9}$ (guar gum $2 \%$ ) and $8.10 \%$ in $\mathrm{T}_{16}$ (chickpea $10 \%+$ guar gum $1 \%$ ) where as least dietary fiber content $(6.72 \%)$ was found in $\mathrm{T}_{1}$ (commercial wheat flour). It is apparent from the results that variations $(\mathrm{P}<0.000)$ exist regarding dietary fiber in chapaties prepared from different composite flours. Maximum dietary fiber $8.16 \%$ was observed in chapaties prepared from $\mathrm{T}_{10}$ (guar gum $3 \%$ ) followed by $7.48 \%$ in $\mathrm{T}_{9}$ (guar gum $2 \%$ ) and $7.43 \%$ in $\mathrm{T}_{16}$ (chickpea $10 \%+$ guar gum $1 \%$ ) where as minimum dietary fiber content $(6.03 \%)$ was found in chapaties prepared from 
$\mathrm{T}_{1}$ (commercial wheat flour). Moreover, $\mathrm{T}_{14}$ (chickpea 5\%+ guar gum 1\%) also exhibited a dietary fiber value of $7.28 \%$ with non significant differences with $\mathrm{T}_{16}$. The values in Figure 1, illustrated that percent augmentation of dietary fiber in chapaties prepared from guar gum 3\% $\left(\mathrm{T}_{10}\right.$ ) was $35.32 \%$ followed by $\mathrm{T}_{9}$ (guar gum $2 \%$ ) i.e. $24.05 \%$ and $\mathrm{T}_{14}$ (chickpea $5 \%+$ guar gum $1 \%$ ) i.e. $20.73 \%$ as compared to control. There is a progressive increase in dietary fiber with the adding up of guar gum. The addition of guar gum not only enhanced dietary fiber but also increased one of its important fraction i.e. soluble fibers, which play a key role to control glucose, obesity and cholesterol in the body. It is suggested from the present study that ingestion of chapaties prepared from composite flours containing guar gum 3\% followed by guar gum $2 \%$ and chickpea $5 \%+$ guar gum $1 \%$ provides an additional dietary fiber that would be supportive for the hyperglycemic people.

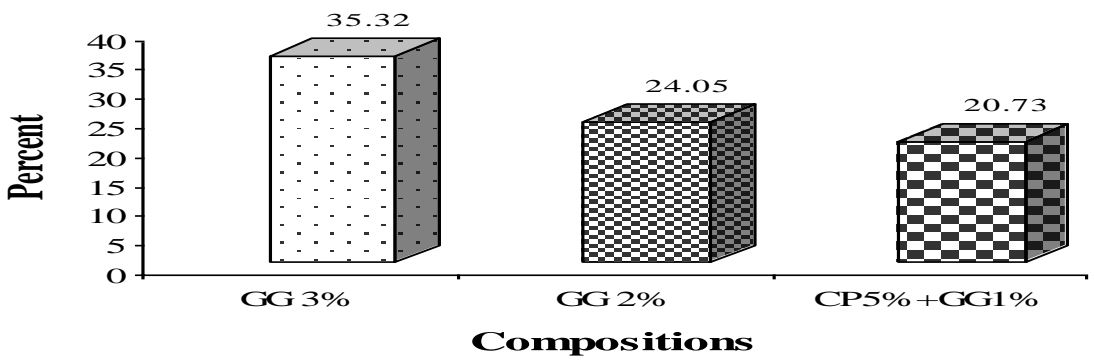

Figure 1. Percent increase in dietary fiber of chapaties prepared from different flour samples compared to control.

Sensory Evaluation: 'Chapati' is the staple diet of sub-continent; the consumer favors a chapati of light brown and creamy in color which can be smashed to pieces of the desired size and folded to form a scoop. The sensory evaluation of chapati for various sensory attributes such as color, flavor, taste, texture, foldingability, chewingability was carried out at and the overcome of all sensory attributes is presented in the form of total chapati scores. Means for total chapati scores and their sum of all sensory attributes showed (Figure 2). 


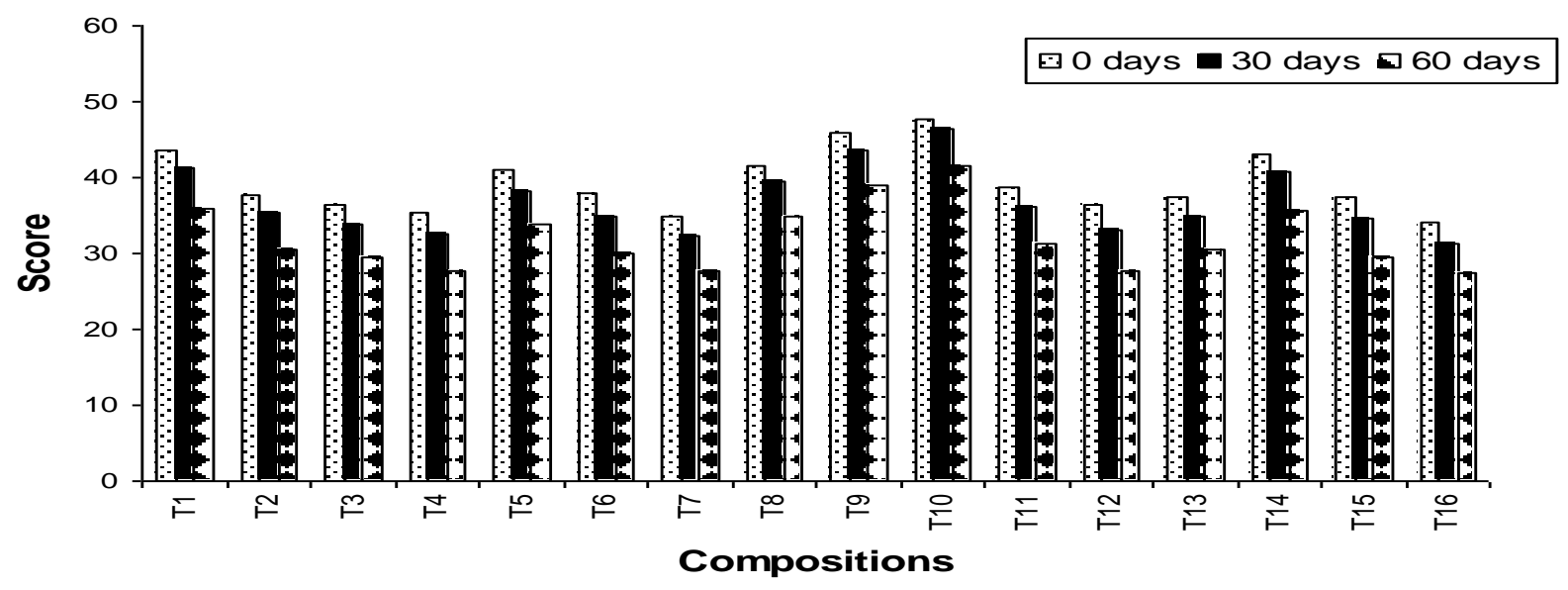

Figure 2 Total chapati score.

$\mathrm{T}_{1}=$ Commercial wheat flour

$\mathrm{T}_{2}=$ lentil $5 \%$

$\mathrm{T}_{3}=$ lentil $7.5 \%$

$\mathrm{T}_{4}=$ lentil $10 \%$

$\mathrm{T}_{5}=$ chickpea $5 \%$

$\mathrm{T}_{6}=$ chickpea $7.5 \%$

$\mathrm{T}_{7}=$ chickpea $10 \%$

$\mathrm{T}_{8}=$ guar gum $1 \%$

$\mathrm{T}_{9}=$ guar gum $2 \%$

$\mathrm{T}_{10}=$ guar gum $3 \%$

$\mathrm{T}_{11}=$ lentil $5 \%+$ guar gum $1 \%$

$\mathrm{T}_{12}=$ lentil $7.5 \%+$ guar gum $1 \%$

$\mathrm{T}_{13}=$ lentil $10 \%+$ guar gum $1 \%$

$\mathrm{T}_{14}=$ chickpea $5 \%+$ guar gum $1 \% \mathrm{~T}_{15}=$ chickpea $7.5 \%+$ guar gum $1 \%$

Chapaties prepared from $T_{10}$ flour acquired the highest scores i.e. 45.27 (47.80, 46.40 and 40.60 at 0,30 and 60 days, respectively) followed by $\mathrm{T}_{9}$ i.e. 42.87 (46.00, 43.60, and 39.00 at 0,30 and 60 days, respectively). Moreover, $\mathrm{T}_{1}$ i.e. 40.27 (43.60, 41.20 and 36.00 at 0, 30 and 60 days, respectively) where as $\mathrm{T}_{16}$ (chickpea $10 \%+$ guar gum $1 \%$ ) got the lowest total chapati scores i.e. 31.00 (34.20, 31.40 and 27.40 at 0,30 and 60 days, respectively). It was further observed that $\mathrm{T}_{14}$ got 39.87 (43.20, 40.80 and 35.60 at 0,30 and 60 days, respectively) scores with non-significant differences to $\mathrm{T}_{1}$.

Physical Parameters: Means for feed, water intake, and gain in body weight of different groups of rats fed on different treatment have been presented in Table 4.

Table 4. Feed intake, water intake, gain in body weight and serum bio-chemical profile in different groups of rats (Means \pm standard deviation).

\begin{tabular}{|c|c|c|c|c|c|c|}
\hline Parameter & Control & GG $3 \%$ & GG $2 \%$ & $\begin{array}{c}\text { CP5\%+GG1 } \\
\%\end{array}$ & $\begin{array}{c}\mathrm{P} \\
\text { value }\end{array}$ & $\begin{array}{l}\text { Confidence } \\
\text { Intervals }\end{array}$ \\
\hline $\begin{array}{l}\text { Feed intake } \\
\text { (g/rat/day) }\end{array}$ & $\begin{array}{l}17.13^{\mathrm{a}} \\
\pm 0.07\end{array}$ & $\begin{array}{l}15.95^{\mathrm{d}} \\
\pm 0.08\end{array}$ & $\begin{array}{l}16.45^{\mathrm{c}} \\
\pm 0.10\end{array}$ & $\begin{array}{l}16.92^{\mathrm{b}} \\
\pm 0.08\end{array}$ & 0.001 & $16.35-16.88$ \\
\hline $\begin{array}{l}\text { Water intake } \\
\text { (mL/rat/day) }\end{array}$ & $\begin{array}{c}28.10^{\mathrm{d}} \\
\pm 0.18\end{array}$ & $\begin{array}{c}30.48^{\mathrm{a}} \\
\pm 0.14\end{array}$ & $\begin{array}{c}29.94^{\mathrm{b}} \\
\pm 0.17\end{array}$ & $\begin{array}{c}29.32^{\mathrm{c}} \\
\pm 0.16\end{array}$ & 0.000 & $28.95-29.97$ \\
\hline $\begin{array}{l}\text { Gain in body } \\
\text { weight } \\
\text { (g/rat/week) }\end{array}$ & $6.96^{\mathrm{a}} \pm 0.16$ & $6.41^{c} \pm 0.19$ & $6.55^{b} \pm 0.08$ & $6.99^{\mathrm{a}} \pm 0.15$ & 0.000 & $6.58-6.87$ \\
\hline $\begin{array}{l}\text { Serum glucose } \\
(\mathrm{mg} / \mathrm{dL})\end{array}$ & $\begin{array}{l}112.50 \\
{ }^{\mathrm{a}} \pm 0.74\end{array}$ & $\begin{array}{l}99.41 \\
{ }^{c} \pm 0.81\end{array}$ & $\begin{array}{l}101.70 \\
\mathrm{~b}_{ \pm} \pm 0.83\end{array}$ & $\begin{array}{c}96.11 \\
{ }^{d} \pm 0.69\end{array}$ & 0.000 & 98.88-105.97 \\
\hline Serum protein & $6.33^{\mathrm{b}} \pm 0.01$ & $6.30^{\mathrm{b}} \pm 0.01$ & $6.32^{\mathrm{b}} \pm 0.01$ & $6.39^{\mathrm{a}} \pm 0.01$ & 0.000 & $6.32-6.35$ \\
\hline
\end{tabular}




\begin{tabular}{lllllll}
\hline (g/dL) & & & & & \\
Serum albumin & $3.60^{\text {ab }}$ & $3.55^{\mathrm{b}} \pm 0.01$ & $3.58^{\mathrm{b}} \pm 0.01$ & $3.63^{\mathrm{a}}$ & 0.003 & $3.57-3.61$ \\
$(\mathrm{~g} / \mathrm{dL})$ & \pm 0.01 & & & \pm 0.01 & & \\
\hline
\end{tabular}

Means showing similar lettering in a row were not statistically different to each at $1 \%$ level of significance

Control=Commercial wheat flour; GG3\% = Guar gum 3\%; GG2\% = Guar gum 2\%; CP+GG = Chickpea 5\% + Guar gum 1\%;

It is apparent from the results that rats fed on control diet had the highest feed intake (17.13 $\mathrm{g} /$ day) followed by the rats fed on diets containing chickpea $5 \%+$ guar gum $1 \%(16.92 \mathrm{~g} / \mathrm{day})$ and guar gum $2 \%$ (16.45 g/day). It was also observed that the lowest feed intake was in the diet containing guar gum 3\% (15.95 g/day). Figure 3 depicted percent reduction of feed intake in different groups of rats as compared to control group. It was found that guar gum $3 \%$ resulted in $6.89 \%$ decrease in feed intake followed by decrease of $3.97 \%$ and $1.23 \%$ for guar gum $2 \%$ and chickpea $5 \%+$ guar gum $1 \%$, respectively $(\mathrm{P}=0.001)$. Study period significantly affected the feed intake in rats. The results showed that highest feed intake was observed on $6^{\text {th }}$ week $(17.82 \mathrm{~g})$ followed by $8^{\text {th }}(17.61 \mathrm{~g})$ week and $5^{\text {th }}(17.56 \mathrm{~g})$ while the lowest feed intake was observed in $1^{\text {st }}$ week $(15.08 \mathrm{~g})$ followed by $2^{\text {nd }}$ week $(15.57 \mathrm{~g})$ per rat per day.

It is apparent from the results (Table 4) that highest water intake $(30.48 \mathrm{ml} / \mathrm{day})$ was observed in rats fed on diet containing guar gum $3 \%$ followed by $(29.94 \mathrm{ml} / \mathrm{day})$ in guar gum $2 \%$ and $(29.32 \mathrm{ml} /$ day $)$ in rats consuming chickpea $5 \%+$ guar gum $1 \%(\mathrm{P}<0.000)$. Lowest water intake $(28.10 \mathrm{ml} / \mathrm{day})$ was observed in control (commercial wheat flour). There is a progressive increasing trend in water consumption by increasing guar gum in the diet. From percent increase of water intake in different groups of rats with reference to control (Figure. 3), it was established that guar gum 3\% resulted (8.47\%) increase in water intake followed by guar gum 2\% (6.55\%) and chickpea 5\%+ guar gum $1 \%(4.34 \%)$ as compared to control. Water intake was not affected appreciably and all groups of rats followed a parallel trend during the entire study period.

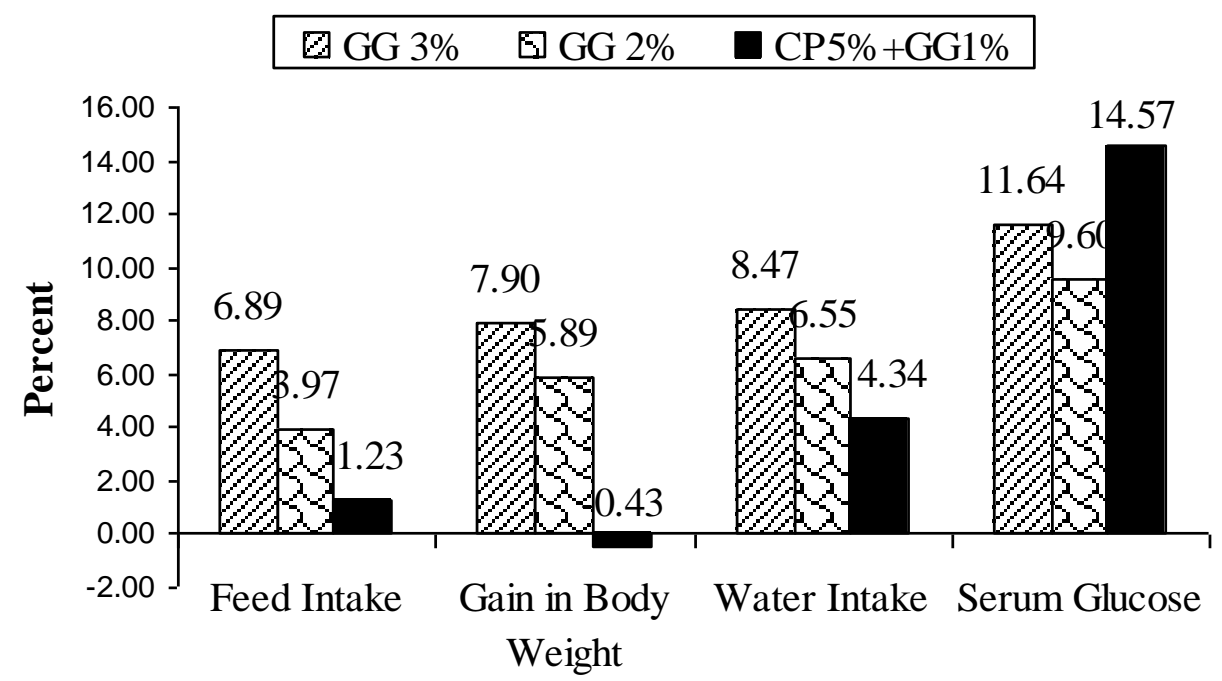

\section{Compositions}

Figure 3. Percent decrease of feed intake, gain in body weight, serum glucose and increase in water intake in different groups of rats compared to control. 
The body weight of the rats varied with age as well as sex. In the first sex weeks, there is the highest increase in body weight while with the passage of time, progressive decrease in gain in body weight was seen. Likewise, the male rats gain more weight than the female rats of the same age. Highest gain in body weight $(\mathrm{P}<0.000)$ was observed in rats fed on diets containing chickpea $5 \%$ + guar gum $1 \%$ (6.99g per rat/week) and control (6.96g per rat/week). It showed that both had non significantly different to each other followed by guar gum $2 \%$ (6.55g per $\mathrm{rat} /$ week) while the lowest body weight gain was noted in guar gum 3\% (6.41g per rat/week) fed rats (Table 4). It was established (Figure 3) that rats fed on guar gum 3\% showed highest decrease in gain in body weight $7.90 \%$ followed by $5.89 \%$ in rats fed on guar gum $2 \%$. However non-significant differences were observed in case of chickpea 5\% + guar gum $1 \%$ with reference to, control. The results with respect to study period showed that highest gain in body weight was observed in $4^{\text {th }}$ week $(9.23 \mathrm{~g})$ followed by $5^{\text {th }}$ week $(7.91 \mathrm{~g})$ and $2^{\text {nd }}$ week $(7.73 \mathrm{~g})$ per rat per week. Similarly, an increase $(4.35 \mathrm{~g})$ in gain in body weight was observed in $1^{\text {st }}$ week. After $4^{\text {th }}$ week, decreasing trend for gain in body weight was observed in all groups of rats but this decrease was more pronounced in rats fed on guar gum 3\%. It is concluded from the present exploration that guar gum 3\% followed by guar gum $2 \%$ by amalgamation in chapati is supportive for the management of weight loss and obesity.

Organs Weight: Means for organs weight of different groups of rats express that diets prepared from selected compositions of composite flours have meaningful effect on intestine weight and intestine length of rats where as liver, heart, lungs, spleen, left kidney and right kidney remained unaffected by using various diets (Table 5). Maximum intestine weight $(8.06 \mathrm{~g}$ ) was observed in rats fed on guar gum 3\%, followed by guar gum 2\% (7.98g) where as non-significant increase was observed in control (7.68g) and chickpea 5\% + guar gum 1\% (7.64g) group ( $\mathrm{P}=0.0365)$. Dietary fiber supplementation in the form of guar gum resulted in increase of intestinal length $(\mathrm{P}=000)$. The mean values for intestine length of different groups of rats explored that diets prepared from various compositions significantly affected intestine length. Rats fed on both guar gum 3\% and guar gum 2\% showed maximum intestine length i.e. 1.17 and $1.16 \mathrm{~m}$, respectively. In case of chickpea $5 \%+$ guar gum $1 \%$, intestine length remained unaffected $(1.11 \mathrm{~m})$ with reference to control group $(1.10 \mathrm{~m})$. It was found that guar gum $3 \%$ resulted in maximum increase $(6.36 \%)$, followed by guar gum $2 \%(5.45 \%)$ where as non significant difference $(0.91 \%)$ was noted in rats fed on chickpea $5 \%+$ guar gum $1 \%$ in comparison with control group.

Table 5 Organ weight of different groups of rats (Means \pm standard deviation).

\begin{tabular}{lcccccc}
\hline Organ weight & Control & GG 3\% & GG 2\% & CP5\%+GG1\% & $\begin{array}{c}\text { P } \\
\text { value }\end{array}$ & $\begin{array}{c}\text { Confidence } \\
\text { intervals }\end{array}$ \\
\hline Liver $(\mathrm{g} / 100 \mathrm{~g})$ & $4.25 \pm 0.07$ & $4.21 \pm 0.05$ & $4.22 \pm 0.05$ & $4.20 \pm 0.05$ & 0.9271 & $4.15-4.27$ \\
Heart $(\mathrm{g} / 100 \mathrm{~g})$ & $0.574 \pm 0.01$ & $0.532 \pm 0.01$ & $0.536 \pm 0.01$ & $0.548 \pm 0.01$ & 0.1290 & $0.534-0.561$ \\
Lungs $(\mathrm{g} / 100 \mathrm{~g})$ & $0.992 \pm 0.03$ & $0.970 \pm 0.02$ & $0.978 \pm 0.02$ & $0.939 \pm 0.01$ & 0.4355 & $0.946-0.994$ \\
Spleen $(\mathrm{g} / 100 \mathrm{~g})$ & $0.347 \pm 0.01$ & $0.322 \pm 0.01$ & $0.315 \pm 0.01$ & $0.336 \pm 0.02$ & 0.0932 & $0.320-0.340$ \\
Right kidney & $0.529 \pm 0.01$ & $0.513 \pm 0.01$ & $0.508 \pm 0.01$ & $0.493 \pm 0.01$ & 0.0862 & $0.501-0.521$ \\
(g/100g) & & & & & & \\
Left kidney & $0.566 \pm 0.01$ & $0.547 \pm 0.01$ & $0.548 \pm 0.01$ & $0.546 \pm 0.01$ & 0.7532 & $0.537-0.567$ \\
\hline
\end{tabular}




\begin{tabular}{lcccccc}
\hline $\begin{array}{l}\mathrm{g} / 100 \mathrm{~g}) \\
\text { Intestine }(\mathrm{g})\end{array}$ & $7.68^{\mathrm{b}} \pm 0.12$ & $8.06^{\mathrm{a}} \pm 0.13$ & $\begin{array}{c}7.98 \\
\mathrm{ab}^{2} \pm 0.13\end{array}$ & $7.64^{\mathrm{b}} \pm 0.10$ & 0.365 & $7.71-7.96$ \\
$\begin{array}{l}\text { Intestine } \\
\text { length }(\mathrm{m})\end{array}$ & $1.10^{\mathrm{b}} \pm 0.01$ & $1.17^{\mathrm{a}} \pm 0.01$ & $1.16^{\mathrm{a}} \pm 0.00$ & $1.11^{\mathrm{b}} \pm 0.00$ & 0.000 & $1.12-1.15$ \\
\hline
\end{tabular}

Means showing similar lettering in a row were not statistically different to each at $1 \%$ level of significance Control=Commercial wheat flour; GG3\% = Guar gum 3\%; GG2\% = Guar gum 2\%; CP+GG = Chickpea 5\% + Guar gum 1\%;

\section{Analysis of Serum Bio-Chemical Profile}

Serum Glucose: Regarding serum glucose, It is apparent (Table 4) that there exists high variation $(\mathrm{P}<0.000)$ variations among different groups of rats fed on various diets of composite flours. Maximum glucose concentration was found to be $112.50 \mathrm{mg} / \mathrm{dL}$ in control group followed by 101.70 and $99.41 \mathrm{mg} / \mathrm{dL}$ in groups fed on guar gum $2 \%$ and guar gum $3 \%$, respectively. Lowest glucose concentration $(96.11 \mathrm{mg} / \mathrm{dL})$ was observed in rats fed on the combination of chickpea 5\%+ guar gum 1\%. Percent decrease of glucose concentration (Figure 3 ) in different groups of rats with reference to control explicated that chickpea 5\%+guar gum $1 \%$ showed maximum reduction (14.57\%) followed by guar gum $3 \%$ and guar gum $2 \%$ which induced $11.64 \%$ and $9.60 \%$ reduction in glucose as compared to control. The glucose level in rats also varied with age and sex. In young male rats, the glucose level ranged from 80-120 $\mathrm{mg} / \mathrm{dL}$. From the present investigation, it was concluded that there is $10-14 \%$ decline in glucose by the addition of selected compositions. Keeping in view the present findings, it is desirable to incorporate chickpea and guar gum at the mandatory levels as proved in the study in the staple diet i.e. chapati, to reduce serum glucose level of hyperglycemic persons.

Serum Protein: Significant differences regarding serum protein were observed in different groups of rats fed on various diets Table 4. Maximum serum protein concentration was found to be $6.39 \mathrm{~g} / \mathrm{dL}$ in rats fed on combination of chickpea $5 \%+$ guar gum $1 \%$ while the remaining three groups showed non significant variations with respect to each other $(\mathrm{P}<0.000)$. Means for serum protein were $6.33,6.30$, and $6.32 \mathrm{~g} / \mathrm{dL}$ for control, guar gum $3 \%$, and guar gum $2 \%$, respectively. From the present investigation, it is concluded that almost all groups of rats followed the similar trend for serum protein except for chickpea 5\% + guar gum 1\% fed group in which there is a slight increase in the protein as contrast to control.

Serum Albumin: As obvious from Table 4, significant contribution of various compositions has been noted for albumin $(\mathrm{P}=0.003)$. Maximum serum albumin concentration was found to be 3.63 $\mathrm{g} / \mathrm{dL}$ in rats fed on combination of chickpea 5\%+ guar gum $1 \%$ showing non-significant differences than that of control $(3.60 \mathrm{~g} / \mathrm{dL})$. Remaining two groups i.e. guar gum $3 \%$ and guar gum $2 \%$ showed non-significant variation with respect to each other. Means for serum albumin were 3.55 and $3.58 \mathrm{~g} / \mathrm{dL}$ for guar gum $3 \%$ and guar gum $2 \%$, respectively however; they also showed non-considerable differences with control.

\section{DISCUSSION}


Dietary Fiber: Dietary fiber may be defined as food components not broken by human alimentary tract enzymes like hemicelluloses, pectic substances, gums, mucilages, cellulose and lignin as well as undigested protein and lipid [4]. The average value for dietary fiber in wheat flour (70-80\% extraction) was $3.6 \%$ while whole grain flour contains $14.4 \%$ on dry weight basis consisting of 1-3\% of soluble fiber [42]. Additional daily intake of $10 \mathrm{~g}$ fiber appeared to lower the risk of coronary death by $17 \%[43,44]$. In the current research, commercial wheat flour was used having dietary fiber content $6.72 \%$. Guar gum is a rich source of dietary fiber providing approximately $85 \%$ on dry weight basis [45] that is the main reason to have a higher dietary fiber content of composite flour samples containing guar gum. In the present study, different legumes are tested in chapati with the idea to increase the dietary fiber to control blood glucose and weight gain through the staple diet of the region. Dietary fiber is inevitable for hyperglycemic individuals because $1 \mathrm{~g}$ of soluble fiber from oats, psyllium, pectin, or guar gum produced changes in total cholesterol of $-0.037,-0.028,-0.070$, and $-0.026 \mathrm{mmol} / \mathrm{L}(-1.42,-1.10,-2.69$, and $-1.13 \mathrm{mg} / \mathrm{dL})$, respectively. LDL cholesterol was $-0.032,-0.029,-0.055$, and $-0.033 \mathrm{mmol} / \mathrm{L}(-$ $1.23,-1.11,-1.96$, and $-1.20 \mathrm{mg} / \mathrm{dL}$ ), respectively [18].

\section{Sensory Evaluation:}

During the present work, conditions were identical for the preparation of chapaties however, the significant effect of legumes and their combinations showed a strong impact on total chapati scores. The decreasing trend in the total chapati scores during storage may be due to the development of rancidity, proteolytic \& lipolytic activity and probably due to mold and infestation. The chapaties prepared from $\mathrm{T}_{10}$ (guar gum $3 \%$ ), followed by $\mathrm{T}_{9}$ (guar gum $2 \%$ ) and $\mathrm{T}_{14}$ (chickpea $5 \%$ + guar gum 1\%) along with $\mathrm{T}_{1}$ (commercial wheat flour) got the highest total chapati scores and were preferred over the others by the judges. In the present study, different composite flour samples affected the overall chapati quality due to variations in chemical, rheological, and sensory attributes. Besides, addition in the level of dietary fiber, legumes also result an increase in micronutrients. Moreover, there were several factors such as preparation of dough, protein content \& quality, diastatic activity, water absorption and damaged starch, which influence the quality of product [13]. In another study barley flour mixed with wheat flour produced a better overall bread quality that was acceptable to the consumers [46].

Physical Parameters: The rats fed on guar gum had reduced feed intake, thus concluding that the guar gum could potentially be effective against obesity in humans [9]. In addition, guar gum and oat beta-glucan reduced the feed intake in Sprague Dawley rats [47]. Some other researcher's work also favored the existing results, as ingestion of palatable granulated guar gum (10 g twice a day) in obese subjects, reduced hunger significantly better than commercially available bran taken in the same way [21]. The long-term effects of guar gum in male adolescent rats were also observed that guar gum group consumed less diet throughout the entire study [28]. Lately it was also proved that guar gum induced a significant decrease in feed intake [48].

Guar gum fed rats had reduced gain in body weight since guar gum is a rich source of soluble dietary fiber [9] and present findings proved that addition of guar gum in the diet is supportive to diminish the gain in body weight, which is ultimately helpful to control overall 
body weight. It has already been established from the various studies that dietary fiber may have some potential in the management of weight loss. This effect is derived from the potential influence of fiber on several aspects of food intake and nutrient availability [22]. The effects on weight loss are often deduced from effects on satiety, decreased caloric intake, and increased fecal excretion of energy in the form of fat and nitrogen [23-25]. Gel forming fibers such as guar gum is more effective in promoting weight reduction than non-gel forming fibers like wheat bran [26]. The guar gum group consumed less diet throughout the study period and gained less weight over the first 20 weeks compared to the cellulose and bran groups [28] just like the present efforts.

Research trials conducted, explored that body weight was significantly reduced during guar gum treatment (10g twice daily) [21]. Later on modified guar gum (GG) appeared to affective in appetite and body weight (BW) loss in humans [30]. Semi solid meal with GG reduced the body weight i.e. $5.6 \pm 1.0 \mathrm{~kg}$. Daily intake of guar gum results in a permanent weight loss. In contrast, a gain in body weight of rats fed on fortified samples of wheat with gram flour [31]. Weight gain over the balanced period and food conversion ratio decreased, linearly with increasing guar gum intake [32]. Fiber consisted of guar gum, gum Arabic, locust bean gum, pectin, and oat fiber reduced body weight by 6 pounds [49]. Moreover gain in body weight of animals fed on diets with pulse starches (red gram, black gram, green gram, Bengal gram) was observed and found to be significantly lower as compared to body weight gain with cereal starch (maize, wheat, rice, jowar, ragi) diet [50]. Recently a significant decrease in weight gain was also concluded by guar gum [48].

Organs Weight: Dietary fiber especially soluble fiber, because of their viscous and gel forming nature, showed significant affect on intestine length and weight. In this study organ, weights of different groups of rats fed on various diets prepared from composite flours resulted in greater small intestine weight relative to body weight [33]. The present conclusions are further supported by another study, which explored that diets containing 0,10 and $20 \%(\mathrm{w} / \mathrm{w})$ guar gum $(75 \%$ soluble fiber, $7.6 \%$ insoluble fibers) fed to normal male Wistar rats $(107.0 \pm 9.3 \mathrm{~g})$ for 60 days showed $10 \%$ increase in small intestine length and $25 \%$ retardation in the intestinal transit time [9].

\section{Analysis of Serum Bio-Chemical Profile}

Serum Glucose: The results in present investigation are in corroboration with the previous findings of various workers, that legume and pulses are helpful in the management of serum glucose. In a study, $24.56 \%$ reduction in serum glucose, by incorporating guar in bread was reported [51]. The effectiveness of guar gum is authenticated by the fact that the hyperglycemia and hyperlipidemia can be controlled by a herbal powder consisting of guar gum, methi, tundika, and meshasringi. The herbal powder was given twice a day before major meals for four weeks [52]. The potential positive effects of chickpea in diabetes therapy and its role as biological active food supplements have been proved [53]. Metabolic response to short and long-term guar gum consumption were studied in adolescent and adult rats. Reduced plasma glucose was measured for only the guar gum group [28]. Hypoglycemic effect of guar gum indicated by the 
addition of guar to an intragastric glucose load $(1 \mathrm{~g} / \mathrm{kg})$ which markedly delayed the rise in plasma glucose levels when the concentration of the gum was adequate $(10 \mathrm{mg} / \mathrm{ml})$. Guar gum can reduce fasting blood glucose from $11.4 \pm 3.7 \mathrm{mmol} \mathrm{L}^{-1}$ to $9.5 \pm 3.9 \mathrm{mmol} \mathrm{L}^{-1}$ in rats $[54,55]$.

Various other researchers also proved the phenomena of hypoglycemia due to guar and guar by-products (GBP) which affected carbohydrate tolerance in rats. Both $1 \%$ and $10 \%$ GBP suspensions administered immediately before a glucose challenge $(1 \mathrm{~g} / \mathrm{kg}$ body weight) caused a $31 \%$ reduction in the integrated plasma glucose response area during a 180 minutes test [56]. Guar gum showed greater viscosity than the other gums during acidification and/or alkalinization and also showed larger effects on plasma glucose levels (35\% reduction in maximum rise in plasma glucose) and on the total area under the curve of plasma glucose [57].

The acute effect of a single dose of guar gum has been verified to reduce the peak postprandial whole blood glucose levels (about 10\%). Following long-term treatment, a further reduction was seen in the obese subjects with the highest postprandial glucose levels [21]. Clinical impact of fiber supplementation for the reduction of postprandial blood glucose showed $17 \%$ decrease in mean daily plasma glucose concentrations while the area under the curve for 2hour plasma glucose concentrations reduced by 36 percent [49].

Serum Albumin: Serum protein values found in different groups of rats in the present investigation are in close association with hematological clinical chemistry values for male Sprague Dawley rats for total protein that ranged from 6.3-8.2 $\mathrm{g} / \mathrm{dL}$ [58].Another study also reported $6.28 \mathrm{~g} / \mathrm{dL}$ total protein in normal control rats [59].

Competing interests: The authors declare that there are no competing interests.

Author's Contributions: All the authors contributed equally.

\section{CONCLUSION}

Diet based strategy is a right approach as it is economical and assessable to avoid the health risks. The present research explored that diet diversification is an effective tool for the management of serum glucose and body weight. Role of legumes is indispensable to enhance the dietary fiber. Ingestion of chapaties prepared from selected compositions of composite flours providing an additional dietary fiber would be supportive to reduce hyperglycemia and obesity.

\section{REFERENCES}

1. Murthy KS, Urs MK. (1985) Effect of Bengal gram (Cicer arietinum) proteins and lipids on serum and liver cholesterol levels in rats. Food Sci Tech 22, 54-6.

2. Toma RB, Curtis DJ. (1986) Dietary fiber: effect on mineral bioavailability. Food Tech 40, 111-6.

3. Singh U. (1999) Cooking quality of pulses. Food Sci Tech 36, 1-14.

4. Heaton KW. (1983) Human nutrition. Clin Nutr 37(C),155. 
5. Spiller GA. (2001) CRC Handbook of Dietary Fiber in Human Nutrition, $3^{\text {rd }}$ ed. Florida CRC Press 363-5.

6. Anonymous. (2004) A revolution in dietary fiber supplement: Fenuber. Available from:http://www.kbcincusa.com//Fenuber/Fenubernew.html.

7. Dalgetty DD, Baik BK. (2001) Isolation and characterization of dietary fiber from pea, chickpea, and lentil flour. Cereal Chem 63, 236.

8. Achremowicz B, Korus J, Curylo K et al. (2000) The effect of different pulse additives to bread products. Electronic J Polish Agric Univ Series Food Sci and Tech 3, 106-15.

9. Frias ACD, Sgarbieri VC. (1999) Guar gum effects on food intake, blood serum lipids and glucose levels of Wistar rats. Plant Foods Human Nutr 53, 15-28.

10. Pomeranz Y. (1988) Wheat chemistry and technology, $3^{\text {rd }}$ ed. St. Paul MN: Am Assoc Cereal Chem. Inc.

11. Pszczola DE. (2003) Plot thickens, as gums: add special effects. Food Tech 57, 34-7.

12. Edwards CH, Booker LK, Rumph CH et al. (1971) Utilization of wheat by adult man: nitrogen metabolism, plasma amino acids, and lipids. Am J Clin Nutr 24, 181-93.

13. Butt MS. (1997) Physiochemical and Protein Composition of Spring Wheats in Relation to End Use Quality. Ph.D. Thesis. Faisalabad, Pakistan. Deptt Food Tech Univ Agric.

14. Alberto N, Jaime P. (1998) Food fortification: A Tool for Fighting Hidden Hunger. Food and Nutr. Bulletin The UN Univ 19, 1.

15. Brennan CS, Samyue E. (2004) Evaluation of starch degradation and textural characteristics of dietary fiber enriched biscuits. Int J Food Properties 7(3), 647-57.

16. Raza S. (2003) In Report of the APO Seminar on Processing and Utilization of Legumes, held on 9-14 October, 2000 Japan. Asian Productivity Org 205, 23.

17. Kailasapathy K, Perara PAJ, Macneil JH et al. (1985) Improved nutritional value in wheat bread by fortification with full fat winged bean flour. J Food Sci 50, 1693-6.

18. Brown L, Rosner B, Willett Wet al. (1999) Cholesterol lowering effects of dietary fiber: a meta-analysis. Am J Clin Nutr 69, 30-42.

19. Uro ABO, Azrag RM. (2001) Hypoglycemic effect of guar gum and wheat bran enriched bread. Ahfad J 18, 30-6.

20. Bhardwaj PK, Dasgupta DJ, Prashar BSet al. (1994) Control of hyperglycemia and hyperlipidaemia by plant product. J Assoc Physicians 42, 33-5.

21. Krotkiewski M. (1984) Effect of guar gum on body weight, hunger ratings and metabolism in obese subjects. Br J Nutr 52, 97-105.

22. Vahouny GV. (1982) Conclusions and recommendations of the symposium on dietary fiber in health and disease. Am J Clin Nutr 35,152-6. Washington, D.C.

23. Leeds AR. (1985) Dietary Fiber Perspectives - Reviews and Bibliography. London. John Libbey.

24. Vahouny GV. (1985) Dietary fibers: aspects of nutrition, pharmacology and pathology. In Nutritional Pathology - Pathobiochemisrty of Dietary Imbalances. Marcel Dekker 207, 17. New York. 
25. Wisker E, Feldheim W, Pomeranz Y et al. (1985) Dietary fiber in cereals. In: Advances in Cereal Science and Technology, Vol. VII; Pomeranz, Y., Ed.; Am Assoc Cereal Chem. Inc.; St. Paul, MN.; p. 69-238.

26. Krothiewski M, Smith U. (1985) Dietary fiber in obesity. In: Dietary Fibers Perspectives. Leeds, London; John Libbey 61, 7.

27. Smith U. (1987) Dietary fiber, diabetes, and obesity. Int J Obes 1, 27-31.

28. Track NS, Cawkwell ME, Chin BC et al. (1985) Guar gum consumption in adolescent and adult rats: short and long-term metabolic effects. Can J Physiol Pharmacol 63, 1113-21.

29. Blackburn NA, Johnson IT. (1981) The effect of guar gum on the viscosity of the gastrointestinal contents and on glucose uptake from the perfused jejunum in the rat. $\mathrm{Br}$ J Nutr 46, 239.

30. Tuomilehto J, Silvasti M, Manninen V et al. (1989) Guar gum and gemfibrozil - an effective combination in the treatment of hypercholesterolaemia. Atherosclerosis. 76, 71-7.

31. Anwar M. (1980) Studies on the Determination of Optimum Level of Gram Flour Supplementation on the Nutritive Value of Wheat Protein. M. Sc. Thesis. Faisalabad, Pakistan Univ. Agric.

32. Seal CJ, Mathers JC. (2001) Comparative gastrointestinal and plasma cholesterol responses of rats fed on cholesterol free diets supplemented with guar gum and sodium alginate. Br J Nutr 85, 317-24.

33. Wang YH, McIntosh GH. (1996) Extrusion and boiling improve rat body weight gain and plasma cholesterol lowering ability of peas and chickpeas. J Nutr 126, 3054-62.

34. Johnson IT, Gee JM, Mahoney RR et al. (1984) Effect of dietary supplements of guar gum and cellulose on intestinal cell proliferation, enzyme levels and sugar transport in the rat. Br J Nutr 52, 477-87.

35. Haridas, Rao P, Leelavathi K et al. (1986) Test baking of chapati- development of a method. Cereal Chem 63, 297.

36. Prosky LP, Asp NG, Furda I et al. (1984) Determination of total dietary fiber in foods, food products, and total diets: interlaboratory study. J Assoc Anal Chem 67, 1044-52.

37. Land DG, Shepherd R. (1988) Scaling and ranking methods. In Sensory Analysis of Foods. Elsevier Applied Science 155, 85. New York; Piggott, J.R.; Ed.

38. 38. Thomas L, Labor U. (1992) Enzymateischer kinetischer colorimetrischer test (GOD-PAP). Vohl/Manenhagen; Germany. Diagnose 4, 169. Biocon Diagnostik, Hecke 8,34516 .

39. Josephson B, Gyllensward A. (1975) Gesamt protein (Biuret methode) Scand. J. Clin. Lab. Fluitest ${ }^{\circledR}$ TP, Biocon Diagnostik, Hecke 8, 34516 Vohl/Manenhagen; Germany. Invest;9:29.

40. Webster D. (1974) Albumin-BCG (Bromcresol Green Method). Biocon commercial kit. Clin. Chem. Germany. Acta 53,109. Fluitest ${ }^{\circledR}$ ALB-BCG, Biocon Diagnostik, Hecke 8, 34516 Vohl/Manenhagen. 
41. Steel RGD, Torrie JH, Dickey DA. (1997) Principles and Procedures of Statistics - A Biometrical Approach. New York; $3^{\text {rd }}$ Ed. McGraw Hill Book Co. Inc.

42. Frolich W, Hestangen B. (1983) Dietary fiber content of different cereal products in Norway. Cereal Chem 60, 82-83.

43. Morris JN, Marr JW, Clayton DG. (1977) Diet and heart: a postscript. Br Med J 2, 1307.

44. Khaw KT, Barrett CE. (1987) Dietary fiber and reduced ischemic heart disease mortality rates in men and women: a 12-year prospective study. Am J Epidemiol 126, 1093-1102.

45. Pszczola DE. (2003) Plot thickens, as gums: add special effects. Food Technol 57, 3447.

46. Ereifej KI, Al-Mahasneh MA, Rababah TM. (2006) Effect of barley flour on quality of balady bread. Int J Food Properties 9(1), 39-49.

47. Begin F, Vachon C, Jones JD et al. (1989) Effect of dietary fibers on glycemia, insulinemia and on gastrointestinal function in rats. Can J Physiol Pharmacol 67, 126571.

48. Yamada K, Tokunaga Y, Ikeda A et al. (2003) Effect of dietary fiber on the lipid metabolism and immune function of aged Sprague Dawley rats. Biosci Biotechnol Biochem 67, 429-33.

49. Freed SH. (2000) The Clinical Impact of Fiber Supplementation for the Reduction of Postprandial Blood Glucose aAnd Risk Reduction of Complications from Diabetes. Diabetes in Control Newsletter 15, 12-8.

50. Rao CN, Rao BSN. (1978) Influence of starches from different sources on protein utilization in rats. Br J Nutr 40, 1-8.

51.Jenkins DJA, Leeds AR, Gassull MA et al. (1977) Decrease in postprandial insulin and glucose concentrations by guar and pectin. Ann Int Med 86, 20-3.

52. Bhardwaj PK, Dasgupta DJ, Prashar BS et al. (1994) Control of hyperglycemia and hyperlipidaemia by plant product. J Assoc Physicians 42, 33-5.

53. Zulet MA, Macarulla MT, Portillo MP et al. (1999) Lipid and glucose utilization in hypercholesterolemic rats fed a diet containing heated chickpea (Cicer aretinum L.): a potential functional food. Int J Vit \& Nutr Res 69, 403-11.

54. Daumerie C, Henquin JC. (1982) Acute effects of guar gum on glucose tolerance and intestinal absorption of nutrients in rats. Diabetes Metab 8, 1-5.

55. Lalor BC, Bhatnagar D, Winocour PH et al. (1990) Placebo-controlled trial of the effects of guar gum and metformin on fasting blood glucose and serum lipids in obese, type 2 diabetic patients. Diabetes Med 7, 242-5.

56. Chiu SS, Track NS. (1985) Guar by-product improves carbohydrate tolerance in rats. Metabolism 34, 481-5.

57. Brenelli SL, Campos SD, Saad MJ. (1997) Viscosity of gums in vitro and their ability to reduce postprandial hyperglycemia in normal subjects. Braz J Med Biol Res 30, 143740.

58. TTL. (Taconic Technical Library). (2004) Hematological Clinical Chemistry Values Sprague Dawley Rats. Available from: http://www.taconic.com/ . 
59. Rehman M, Varghese Z, Moorhead JF. (2001) Paradoxical increase in nitric oxide synthase activity in hypercholesterolemic rats with impaired renal function and decreased activity of nitric oxide. Nephrol Dial Transplant 16, 262-8. 